\title{
Pengaruh Struktur Aktiva dan Profitabilitas terhadap Struktur Modal (Penelitian pada PT Unilever Indonesia Tbk)
}

\author{
Hani Olivia ${ }^{1}$, Heni Hirawati ${ }^{2}$ \\ Program Studi Manajemen, Universitas Tidar ${ }^{1,2}$ \\ Email korespondensi: hanioliviaa@gmail.com ${ }^{1}$
}

Received: 20 Jul 2021 Reviewed: 30 Jul2021 Accepted: 23 Aug 2021 Published: 31 Oct 2021

\begin{abstract}
The capital structure is a comparison between debts and equity for company funding. Factors that can affect the capital structure include the asset structure and profitability. The purpose of this research was to obtain empirical evidence on the influence of asset structure and profitability on the capital structure. The object of the research was PT Unilever Indonesia Tbk as it is a multinational company so it is predicted to have smaller probability of loss. This research used an associative quantitative approach with multiple linear regression analysis tools. Data used for this study is taken from the annual financial report of PT Unilever Indonesia Tbk period of 2008-2019. Based on the results of data analysis in this study came the conclusion that the asset structure and profitability have a major influence on the capital structure.
\end{abstract}

Keywords: asset structure, profitability, capital structure, funding

\begin{abstract}
ABSTRAK
Struktur modal adalah perbandingan penggunaan antara hutang dengan ekuitas untuk pendanaan sebuah perusahaan. Faktor-faktor yang dapat memengaruhi struktur modal antara lain struktur aktiva dan profitabilitas. Tujuan dari penelitian ini adalah untuk mendapatkan bukti empiris mengenai pengaruh struktur aktiva dan profitabilitas terhadap struktur modal pada PT Unilever Indonesia Tbk. Objek penelitian dilakukan pada PT Unilever Indonesia Tbk karena merupakan perusahaan multinasional sehingga diprediksi bahwa kecil kemungkinan mengalami kerugian. Penelitian ini dilakukan menggunakan pendekatan kuantitatif asosiatif dengan alat analisis regresi linier berganda. Data yang digunakan berupa laporan keuangan tahunan PT Unilever Indonesia Tbk periode tahun 2008-2019. Berdasarkan hasil analisis data dalam penelitian ini diperoleh kesimpulan bahwa struktur aktiva dan profitabilitas mempunyai pengaruh yang besar dalam struktur Modal.
\end{abstract}

Kata kunci: struktur aktiva, profitabilitas, struktur modal, pendanaan

\section{A. PENDAHULUAN}

Pasar modal merupakan tempat bertemunya investor sebagai pembeli dan perusahaan sebagai penjual efek. Dari perdagangan efek ini investor akan mendapatkan dividen dan perusahaan akan mendapatkan modal yang digunakan untuk membiayai kegiatan 
operasionalnya. Perancangan struktur modal untuk pendanaan perusahaan tidak boleh dilakukan sembarangan. Modal ini diperoleh atas keputusan dan pertimbangan yang dilakukan oleh manajer. Dalam merancang struktur modal, manajer harus mempertimbangkan seberapa besar porsi permodalan atau pendanaan yang berasal dari hutang, saham preferen, dan saham biasa (Prastika \& Sudaryanti, 2019). Hal ini sejalan dengan pendapat Yusintha \& Suryandari (2010) yang mana keputusan pendanaan sebuah perusahaan akan menggambarkan kemampuannya dalam kegiatan operasional dan juga akan berpengaruh terhadap risiko perusahaan itu sendiri.

Struktur modal adalah perbandingan penggunaan antara hutang dengan ekuitas untuk pendanaan sebuah perusahaan. Menurut Kanita (2014), struktur modal akan menghasilkan tingkat pengembalian tertentu yang berbeda-beda dari setiap sumber dananya. Kombinasi proporsi dalam struktur modal harus dilakukan secara optimal hingga akhirnya akan memaksimalkan nilai perusahaan. Ada beberapa faktor yang mempengaruhi perusahaan dalam keputusan struktur modal menurut McCue dan Ozcan (1992) dalam Prabansari \& Kusuma (2005) diantaranya, struktur aktiva (asset structure), pertumbuhan aktiva (asset growth), kemampuan memperoleh laba (profitability), risiko (risk), ukuran perusahaan (size), pajak (tax shields), struktur kepemilikan perusahaan (ownership/system affiliation), sistem pembayaran dari konsumen (payment system), dan kondisi pasar (market conditions).

Penelitian ini dilakukan untuk mengembangkan penelitian sebelumnya yaitu mengacu pada penelitian yang dilakukan oleh Prastika \& Sudaryanti (2019) mengenai pengaruh struktur aktiva dan profitabilitas terhadap struktur modal (penelitian pada PT Mayora Indah Tbk). Menurut hasil penelitian Prastika \& Sudaryanti (2019) struktur aktiva dan profitabilitas berpengaruh negatif dan tidak signifikan terhadap struktur modal. Hal ini berbeda dengan penelitian yang dilakukan oleh Tijow et al. (2018) yang menemukan bahwa struktur aktiva berpengaruh positif. Hasil penelitain berbeda juga ditemukan Kanita (2014) dimana struktur aktiva juga berpengaruh positif, tetapi tidak secara signifikan terhadap struktur modal. Profitabilitas juga memberikan hasil yang berbeda menurut Kanita (2014) yaitu berpengaruh negatif signifikan terhadap struktur modal.

Oleh karena itu, penelitian ini mencoba untuk menggunakan objek penelitian lain yaitu PT Unilever Indonesia Tbk untuk menguji apakah variabel struktur aktiva dan profitabilitas memberikan hasil yang sama atau berbeda. Tujuan penelitian ini dilakukan adalah juga untuk mendapatkan bukti empiris mengenai pengaruh struktur aktiva dan profitabilitas terhadap struktur modal pada PT Unilever Indonesia Tbk. 
Penelitian dilakukan pada PT Unilever Indonesia Tbk karena perusahaan ini merupakan perusahaan multinasional yang telah memiliki lebih dari 400 merek dagang, dengan 14 merek diantaranya memiliki total penjualan lebih dari $£ 1$ miliar. PT Unilever Indonesia Tbk kini telah tumbuh menjadi salah satu perseroan terdepan dengan kategori fast moving consumer goods di Indonesia dengan rangkaian produknya mencakup merek-merek ternama dunia seperti Pepsodent, Lux, Lifebuoy, Dove, Sunsilk, Clear, Rexona, Vaseline, Rinso, Molto, Sunlight, Wall's, Royco, Bango, dan lainnya. Didasarkan pada PT Unilever Indonesia Tbk adalah produsen rumah tangga terbesar ketiga di dunia sehingga diprediksi bahwa kecil kemungkinan mengalami kerugian.

\section{B. TELAAH PUSTAKA}

\section{Struktur Modal}

Menurut Yusuf \& Yusra (2019) struktur modal merupakan teori yang menjelaskan tentang perimbangan antara hutang jangka panjang dan modal sendiri (ekuitas). Struktur modal yang optimal dapat dicapai dengan meminimalkan biaya modal rata-rata dan adanya perimbangan antara liabilitas dan ekuitas sehingga akan memaksimalkan nilai perusahaan (Zuhro, 2016). Artini \& Puspaningsih (2011) menyatakan variabel struktur modal diukur melalui rasio debt to equity ratio (DER). Menurut Sukamulja (2019) DER mengukur tingkat proporsi hutang yang dijamin oleh modal sendiri sebagai pendanaan perusahaan. Semakin tinggi nilai rasio ini, menunjukkan bahwa semakin tinggi tingkat hutang perusahaan, maka semakin tinggi pula risiko yang ditanggung oleh pemilik perusahaan. Menurut Sukamulja (2019) DER dirumuskan sebagai berikut:

$$
D E R=\frac{\text { total liabilitas }}{\text { total ekuitas }} \times 100 \%
$$

\section{Struktur Aktiva}

Pengertian struktur aktiva menurut Yusintha \& Suryandari (2010) adalah perbandingan proporsi antara total aktiva tetap dengan total aktiva yang dimiliki oleh perusahaan. Menurut Andika \& Sedana (2019) perusahaan yang memiliki porsi aktiva tetap yang lebih tinggi akan cenderung menggunakan hutang lebih banyak karena aktiva tetap dapat dijadikan perusahaan sebagai jaminan atas hutang yang dilakukan. Perbandingan antara total aktiva tetap dengan total aktiva dirumuskan dengan fixed asset ratio (FAR) menurut Devi et al. (2017) yaitu:

$$
F A R=\frac{\text { total aktiva tetap }}{\text { total aktiva }} \times 100 \%
$$


Hasil penelitian terdahulu dari Sudarmika \& Sudirman (2015), Watung et al. (2016), Suweta \& Dewi (2016), Pertiwi \& Darmayanti (2018), Andika \& Sedana, (2019) menunjukkan bahwa struktur aktiva berpengaruh terhadap struktur modal. Dengan demikian, peneliti membuat hipotesis pertama yaitu:

$\mathrm{H}_{1}$ : Struktur aktiva berpengaruh terhadap struktur modal.

\section{Profitabilitas}

Menurut Devi et al. (2017) rumus untuk mengukur profitabilitas adalah ROA (return on asset). Menurut Sukamulja (2019) ROA digunakan untuk mengukur kemampuan perusahaan dalam menghasilkan laba bersih atas aset yang dimiliki sekaligus untuk mengukur tingkat pengembalian investasi yang dilakukan perusahaan. Mengacu pada penelitian yang dilakukan oleh Nawang (2016) ROA dirumuskan sebagai berikut:

$$
R O A=\frac{\text { laba setelah pajak }}{\text { total aktiva }}
$$

Menurut penelitian terdahulu yang dilakukan oleh Watung et al. (2016), Hadianto, (2010), Dewi \& Sudiartha (2017), Wijaya \& Utama (2014), Zuhro (2016), dan Andika \& Fitria (2016) menghasilkan pernyataan bahwa profitabilitas berpengaruh terhadap struktur modal. Maka, peneliti membuat hipotesis kedua, yaitu:

$\mathrm{H}_{2}$ : Profitabilitas berpengaruh terhadap struktur modal.

\section{Struktur Aktiva dan Profitabilitas terhadap Struktur Modal}

Menurut Thausyah \& Suwitho (2015) tingkat profitabilitas yang mengimbangkan dengan hutang perusahaan yang tinggi dianggap memiliki peluang yang bagus. Hasil penelitian yang dilakukan oleh peneliti terdahulu diantaranya Watung et al. (2016), Premawati \& Darma (2017), Maryanti, (2016) memperoleh hasil bahwa struktur aktiva dan profitabilitas berpengaruh terhadap struktur modal. Oleh karena itu, peneliti membuat hipotesis ketiga, yaitu: $\mathrm{H}_{3}$ : Struktur aktiva dan profitabilitas berpengaruh secara simultan terhadap struktur modal

\section{METODE PENELITIAN}

Jenis penelitian yang dilakukan adalah menggunakan pendekatan kuantitatif asosiatif, dilakukan untuk mengetahui hubungan antara dua variabel atau lebih yang digunakan untuk menjelaskan, memprediksi, dan mengontrol suatu gejala guna membangun suatu teori (Anshori \& Iswati, 2019). Alat analisis yang digunakan adalah analisis regresi linear berganda dan diawali dengan uji asumsi klasik yang terdiri dari uji normalitas, uji multikolinearitas, uji heteroskedastisitas, dan uji autokorelasi. Variabel yang digunakan dalam penelitian ini adalah 
struktur aktiva $\left(\mathrm{X}_{1}\right)$ dan profitabilitas $\left(\mathrm{X}_{2}\right)$ sebagai variabel independen, dan struktur modal sebagai variabel dependen (Y).

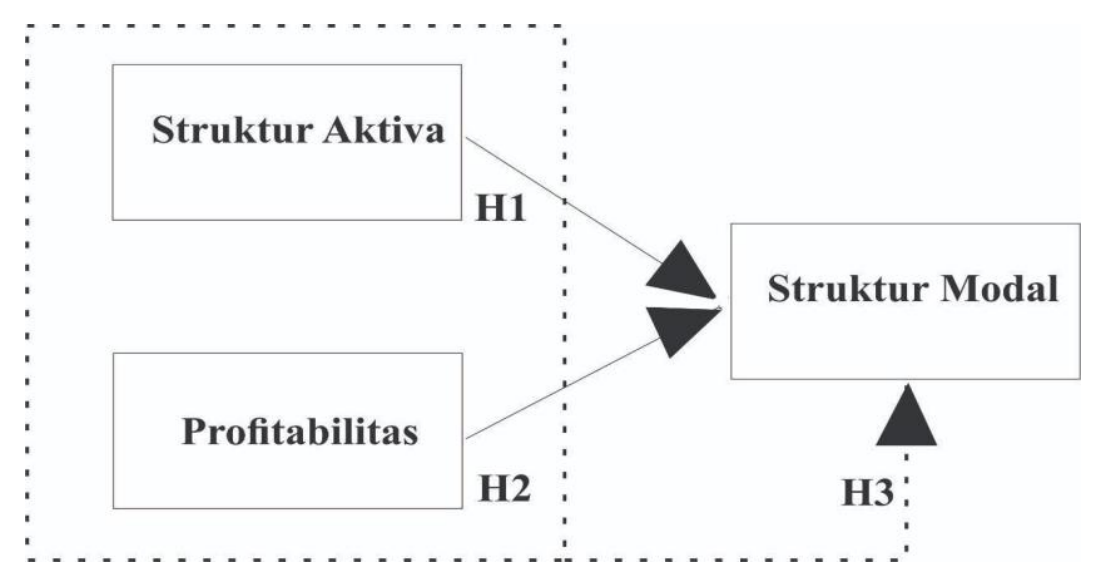

Gambar 1: Kerangka teoritis penelitian

Sumber: penelitian terdahulu

Rasio yang digunakan untuk menghitung variabel struktur aktiva dalam penelitian ini adalah FAR (fixed asset ratio), variabel profitabilitas dihitung menggunakan ROA (return on asset), dan variabel struktur modal dihitung menggunakan rasio DER (debt to equity ratio). Penelitian ini menggunakan data berkala (time series data). Data yang digunakan bersumber dari data laporan keuangan tahunan PT Unilever Indonesia Tbk dari tahun 2008 sampai 2019. Analisis regresi linear berganda digambarkan melalui persamaan berikut:

$$
\mathrm{Y}=\mathrm{a}+\mathrm{b} 1 \mathrm{X} 1+\mathrm{b} 2 \mathrm{X} 2+\mathrm{e}
$$

Keterangan:

$\begin{array}{ll}\alpha & : \text { konstanta } \\ \mathrm{Y} & : \text { struktur modal } \\ \mathrm{X} 1 & : \text { struktur aktiva } \\ \mathrm{X} 2 & \text { : profitabilitas } \\ \text { b1, b2, b3 } & : \text { koefisien regresi } \\ \mathrm{e} & \text { : error }\end{array}$

\section{HASIL DAN PEMBAHASAN}

\section{Deskripsi Data Penelitian}

Berdasarkan tabel 1 dapat dilihat bahwa struktur modal tertinggi PT Unilever Indonesia Tbk terjadi pada tahun 2019 yaitu mencapai 290,95\%. Nilai ini menunjukkan bahwa total 
liabilitas UNVR 2,90 kali lebih besar dari total ekuitasnya yang artinya keseluruhan hutang yang dijamin oleh modal sendiri adalah sebesar Rp 2,90. Sedangkan struktur modal terendah PT Unilever Indonesia Tbk terjadi pada tahun 2009 yaitu sebesar 101,99\%. Nilai ini menunjukkan bahwa total liabilitas UNVR 1,01 kali lebih besar dari total ekuitasnya yang artinya keseluruhan hutang yang dijamin oleh modal sendiri adalah sebesar Rp 1,01. Struktur modal PT Unilever Indonesia Tbk selama periode tahun 2008-2019 cenderung mengalami fluktuasi dan berada pada tingkat di atas $100 \%$.

Tabel 1: Struktur Modal, Struktur Aktiva, dan Profitabilitas PT Unilever Indonesia Tbk Periode Tahun 2008-2019.

\begin{tabular}{llll}
\hline Tahun & Struktur Modal & Struktur Aktiva & Profitabilitas \\
\hline 2008 & $108,58 \%$ & $39,59 \%$ & $37,23 \%$ \\
2009 & $101,99 \%$ & $40,56 \%$ & $40,67 \%$ \\
2010 & $114,75 \%$ & $47,75 \%$ & $38,99 \%$ \\
2011 & $186,87 \%$ & $50,92 \%$ & $39,86 \%$ \\
2012 & $205,76 \%$ & $52,75 \%$ & $40,34 \%$ \\
2013 & $217,41 \%$ & $51,78 \%$ & $40,32 \%$ \\
2014 & $213,92 \%$ & $51,72 \%$ & $40,38 \%$ \\
2015 & $225,85 \%$ & $52,90 \%$ & $37,20 \%$ \\
2016 & $255,97 \%$ & $56,91 \%$ & $38,16 \%$ \\
2017 & $265,46 \%$ & $55,12 \%$ & $37,05 \%$ \\
2018 & $157,62 \%$ & $54,44 \%$ & $46,66 \%$ \\
2019 & $290,95 \%$ & $51,89 \%$ & $35,80 \%$ \\
\hline
\end{tabular}

Sumber: data diolah penulis, 2021

Menurut tabel 1 dapat juga dilihat bahwa struktur aktiva tertinggi PT Unilever Indonesia Tbk terjadi pada tahun 2016 yaitu sebesar 56,91\%. Nilai ini menunjukkan porsi aktiva tetap yang dapat dijadikan perusahaan sebagai jaminan atas hutang yang dilakukan adalah sebesar $56,91 \%$. Semakin tinggi nilai struktur aktiva, maka struktur modal perusahaan yang berasal dari hutang juga semakin besar. Nilai ini juga juga dapat diartikan bahwa setiap rupiah dari total aktiva terdapat aktiva tetap sebesar Rp 0,56. Jadi struktur modal PT Unilever Indonesia Tbk pada tahun 2016 adalah 56,91\% berasal dari hutang. Sedangkan struktur aktiva terendah PT Unilever Indonesia Tbk terjadi pada tahun 2008 yaitu sebesar 39,59\%. Nilai ini menunjukkan porsi aktiva tetap yang dapat dijadikan perusahaan sebagai jaminan atas hutang yang dilakukan adalah sebesar 39,59\%. Jadi pada tahun 2008, PT Unilever Indonesia Tbk lebih 
banyak menggunakan modal sendiri dalam struktur modalnya. Nilai ini juga dapat diartikan bahwa setiap rupiah dari total aktiva terdapat aktiva tetap sebesar Rp 0,39.

Selanjutnya, dapat dilihat bahwa profitabilitas tertinggi PT Unilever Indonesia Tbk terjadi pada tahun 2018 yaitu sebesar 46,66\%. Nilai ini menunjukkan setiap rupiah jumlah aktiva menghasilkan laba bersih sebesar Rp 0,46 dan tingkat pengembalian investasi perusahaan atas aset adalah sebesar $46,66 \%$. Semakin tinggi nilai profitabilitasnya, maka struktur modal perusahaan lebih banyak menggunakan modal sendiri dari tingkat keuntungan yang diperoleh. Sedangkan profitabilitas terendah PT Unilever Indonesia Tbk terjadi pada tahun 2019 yaitu sebesar 35,80\%. Nilai ini menunjukkan setiap rupiah jumlah aktiva menghasilkan laba bersih sebesar Rp 0,35 dan tingkat pengembalian investasi perusahaan atas aset adalah sebesar $35,80 \%$.

\section{Uji Normalitas}

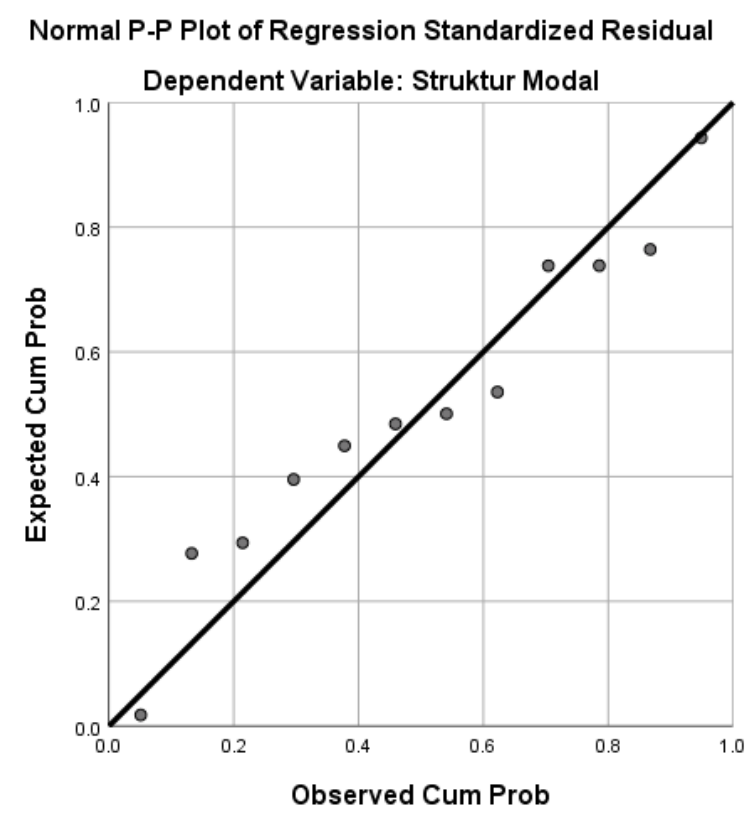

Gambar 2: Hasil Uji Normalitas

Sumber: Data diolah penulis, 2021

Uji normalitas dilakukan untuk melihat apakah dalam model regresi variabel bebas dan variabel terikat memiliki data yang berdistribusi normal atau tidak, menurut (Sugiyono, 2012) cara yang sering digunakan adalah dengan melihat tampilan grafik histogram yang memberikan pola distribusi normal karena menyebar secara merata ke kiri dan ke kanan, atau dapat juga dilihat dari grafik normal P-P plot. Menurut (Ghozali, 2016) menyatakan bahwa model regresi dikatakan berdistribusi normal jika data plotting yang menggambarkan data sesungguhnya 
mengikuti garis diagonal. Pada gambar di atas, grafik normal plot terlihat bahwa titik-titik menyebar di sekitar garis diagonal dan penyebarannya mengikuti arah garis diagonal, dari grafik ini dapat disimpulkan bahwa model garis regresi ini sudah memenuhi asumsi normalitas.

\section{Uji Multikolinearitas}

Uji multikolinearitas digunakan untuk mengetahui ada tidaknya hubungan antar variabel independen. Menurut Sulaiman (2004) multikolinearitas berarti hubungan yang sempurna atau pasti di antara beberapa atau semua variabel independen dari model regresi. Menurut (Ghozali, 2016) tidak terjadi gejala multikolinearitas, jika nilai Tolerance $>0,1000$ dan nilai $\operatorname{VIF}<10,00$. Maka data berdasarkan tabel 2, dapat dikatakan bahwa tidak ada gejala multikolinearitas pada data yang digunakan dalam variabel tersebut.

Tabel 2: Hasil uji t dan uji Multikolinearitas

\begin{tabular}{|c|c|c|c|c|c|c|c|c|}
\hline & \multicolumn{8}{|c|}{ Coefficients $^{a}$} \\
\hline & \multirow{2}{*}{ Model } & \multicolumn{2}{|c|}{$\begin{array}{c}\text { Unstandardized } \\
\text { Coefficients }\end{array}$} & \multirow{2}{*}{$\begin{array}{c}\begin{array}{c}\text { Standardized } \\
\text { Coefficients }\end{array} \\
\text { Beta }\end{array}$} & \multirow{2}{*}{$t$} & \multirow{2}{*}{ Sig. } & \multicolumn{2}{|c|}{ Collinearity Statistics } \\
\hline & & $\boldsymbol{B}$ & $\begin{array}{c}\text { Std. } \\
\text { Error }\end{array}$ & & & & Tolerance & $V I F$ \\
\hline & $\begin{array}{l}\text { (Constant) } \\
\text { Struktur }\end{array}$ & 127.576 & 134.281 & & .950 & .367 & & \\
\hline & Aktiva & 9.748 & 1.548 & .832 & 6.299 & .000 & .990 & 1.010 \\
\hline 1 & Profitabilitas & -10.782 & 2.966 & -.480 & -3.635 & .005 & .990 & 1.010 \\
\hline
\end{tabular}

a. Dependent Variable: Struktur Modal

Sumber: Data diolah penulis, 2021

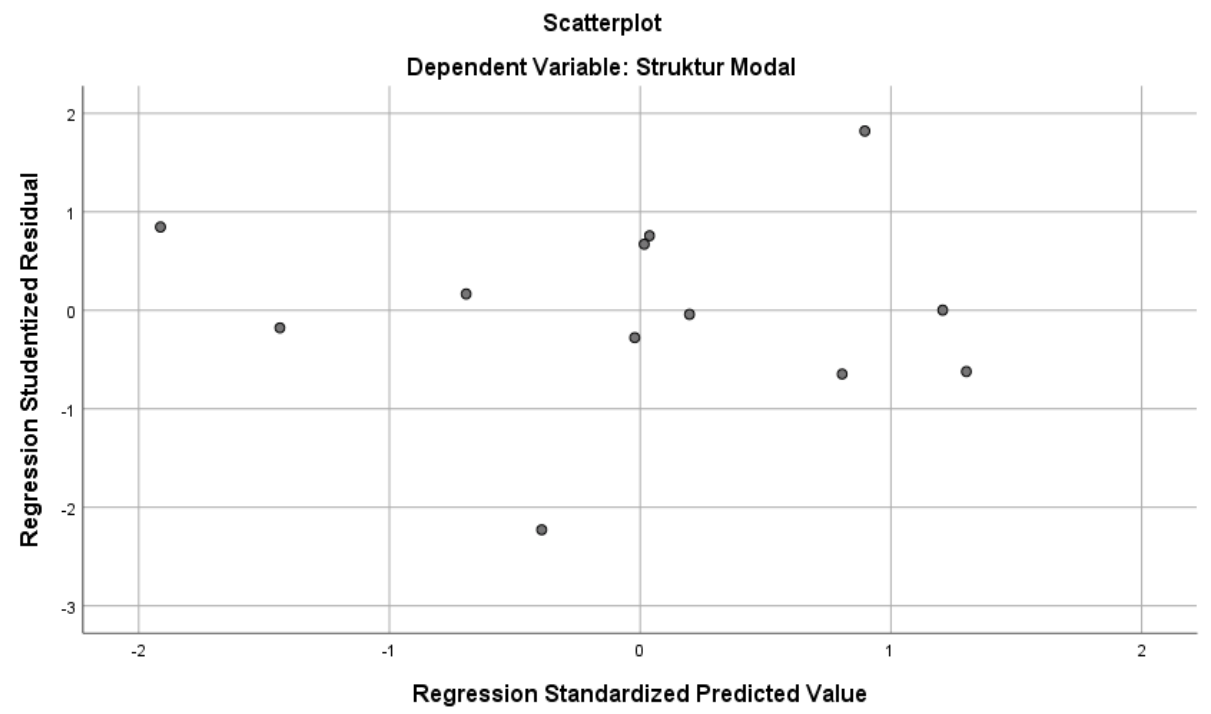

Gambar 3. Hasil Uji Heteroskedastisitas

Sumber: data diolah penulis, 2021 


\section{Uji Heteroskedastisitas}

Berdasarkan gambar 3, menunjukkan bahwa titik-titik menyebar di bawah dan di atas angka 0 , serta tidak membentuk pola maka dapat disimpulkan bahwa pada model regresi tidak terdapat unsur heteroskedastisitas. Menurut Ghozali (2016) tidak terjadi heteroskedastisitas, jika tidak ada pola yang jelas (menggelombang, melebar kemudian menyempit) pada gambar scatterplot, serta titik-titik menyebar di atas dan di bawah angka 0 pada sumbu Y. Maka dari hasil data di atas menyatakan bahwa tidak ada gejala heteroskedastisitas.

\section{Uji Autokorelasi}

Tabel 3: Hasil Uji Autokorelasi

\begin{tabular}{llcccc}
\hline \multicolumn{5}{c}{ Model Summary $^{b}$} \\
\hline Model & $\boldsymbol{R}$ & $\begin{array}{c}\boldsymbol{R} \\
\text { Square }\end{array}$ & $\begin{array}{c}\text { Adjusted } \boldsymbol{R} \\
\text { Square }\end{array}$ & $\begin{array}{c}\text { Std. Error of } \\
\text { the Estimate }\end{array}$ & $\begin{array}{c}\text { Durbin- } \\
\text { Watson }\end{array}$ \\
\hline 1 & $.919^{\mathrm{a}}$ & .844 & .810 & 27.52508 & 1.795 \\
\hline a. Predictors: (Constant), Profitabilitas, Struktur Aktiva & \\
b. Dependent Variable: Struktur Modal
\end{tabular}

Sumber: data diolah penulis, 2021

Menurut Ghozali (2016) suatu data tidak memiliki gejala autokorelasi jika nilai Durbin Watson terletak antara du sampai dengan (4-du). Hasil tabel 3 menyatakan bahwa du $(1,579)$ $<$ Durbin Watson $(1,795)<4$-du $(2,421)$. Dengan demikian berarti bahwa tidak terjadi gejala autokorelasi dalam data yang digunakan dalam penelitian.

\section{Koefisien Determinasi $\left(\mathbf{R}^{2}\right)$}

Dari output tabel 3, didapatkan nilai adjusted $R$ square sebesar 0,844 yang artinya pengaruh variabel independen $(\mathrm{X})$ terhadap variabel $(\mathrm{Y})$ sebesar $84,4 \%$. Variabel independen dalam menjelaskan variasi yang terjadi pada variabel dependen sebesar $84,4 \%$, sedangkan sisanya sebesar $13,6 \%$ dijelaskan oleh variabel atau faktor lain yang tidak dimasukkan ke dalam model ini. Nilai koefisien determinasi sebesar $84,4 \%$ menunjukkan bahwa variabel bebas dalam penelitian memiliki pengaruh yang kuat terhadap variabel terikat.

\section{Uji t}

Untuk menguji pengaruh variabel bebas terhadap variabel terikat secara parsial dilakukan dengan uji t, dalam penelitian ini dilakukan uji parsial untuk mengetahui pengaruh variabel independen, pengaruh kemampuan terhadap variabel dependen. Pengujian parsial dilakukan dua arah, dengan menggunakan tingkat signifikansi 0.05 dan derajat bebas (n-k-1). Menurut Ghozali (2016) jika nilai sig. < 0,05 maka artinya variabel independen (X) secara parsial 
berpengaruh terhadap variabel dependen (Y). Jika nilai t Hitung $>\mathrm{t}$ tabel maka dikatakan berpengaruh. Nilai t tabel adalah $(0,05 / 2 ; 12-2-1)=(0,025: 9)=2,262$. Berdasarkan hasil uji t pada tabel 2, t hitung untuk struktur aktiva sebesar 6,299 dan profitabilitas sebesar 3,635. Maka bisa dilihat dari t hitung lebih besar daripada t tabel. Dari data di atas, menyatakan bahwa variabel struktur aktiva dan variabel profitabilitas berpengaruh secara parsial terhadap variabel struktur modal.

\section{Uji F}

Menurut Ghozali (2016) jika nilai Sig. < 0,05 maka artinya variabel independen (X) secara simultan berpengaruh terhadap variabel (Y). Berdasarkan tabel 4 dapat didapatkan bahwa nilai signifikansi adalah 0.00 lebih kecil dari nilai 0.05 . Selain itu ditemukan F hitung lebih besar dari $\mathrm{F}$ tabel. $\mathrm{F}$ tabel $=(\mathrm{k} ; \mathrm{n}-\mathrm{k})=(2 ; 12-2)=4,10$ dan sementara untuk $\mathrm{F}$ hitungnya adalah sebesar 24,430. Karena 24,430>4,10. Dengan demikian dapat dikatakan bahwa struktur aktiva $\left(\mathrm{X}_{1}\right)$ dan profitabilitas $\left(\mathrm{X}_{2}\right)$ secara simultan berpengaruh signifikan positif terhadap variabel dependen struktur modal (Y).

Tabel 4: Hasil Uji F

\begin{tabular}{llrrrrr}
\hline \multicolumn{7}{c}{ MNOVA $^{\mathrm{a}}$} \\
\hline Model & Sum of Squares & \multicolumn{1}{c}{ df } & Mean Square & F & Sig. \\
\hline 1 & Regression & 37017.867 & 2 & 18508.933 & 24.430 & $.000^{\mathrm{b}}$ \\
& Residual & 6818.670 & 9 & 757.630 & & \\
& Total & 43836.537 & 11 & & & \\
\hline
\end{tabular}

a. Dependent Variable: Struktur Modal

b. Predictors: (Constant), Profitabilitas, Struktur Aktiva

Sumber: data diolah penulis, 2021

\section{Pengaruh Struktur Aktiva terhadap Struktur Modal}

Hasil analisis statistik pada tabel 2 menunjukkan bahwa struktur aktiva mempunyai nilai t hitung lebih besar dari t tabel yaitu 6,299 dan nilai sig. <0,05. Hal ini berarti struktur aktiva berpengaruh terhadap struktur modal. Hasil ini sesuai dengan hipotesis pertama sehingga $\mathrm{H}_{1}$ dapat diterima. Hasil penelitian ini juga sesuai dengan penelitian terdahulu yang dilakukan oleh Sudarmika \& Sudirman (2015), Watung et al. (2016), Suweta \& Dewi, (2016), Pertiwi \& Darmayanti, (2018), dan Andika \& Sedana (2019). Struktur aktiva yang memberikan pengaruh terhadap struktur modal mengartikan bahwa perusahaan memiliki tingkat struktur aktiva tetap yang tinggi yang mana perusahaan akan cenderung menggunakan hutang lebih banyak dengan aktiva tetap sebagai jaminannya. 


\section{Pengaruh Profitabilitas terhadap Struktur Modal}

Hasil analisis statistik pada tabel 2 menunjukkan bahwa profitabilitas memiliki nilai $\mathrm{t}$ hitung 3,635 dan nilai sig. 0,005. Hal ini berarti bahwa profitabilitas memiliki pengaruh terhadap struktur modal. Dengan demikian, dapat disimpulkan bahwa $\mathrm{H}_{2}$ dapat diterima. Hasil penelitian ini juga didukung dengan penelitian sebelumnya yang sudah dilakukan oleh Watung et al. (2016), Hadianto (2010), Dewi \& Sudiartha (2017), Wijaya \& Utama (2014), Zuhro (2016), dan Andika \& Fitria (2016). Profitabilitas berpengaruh terhadap struktur modal mengartikan bahwa perusahaan memperoleh tingkat laba yang tinggi sehingga dapat digunakan sebagai modal internal perusahaan. Hasil penelitian ini memberikan kemungkinankemungkinan bahwa tingkat laba yang diperoleh atas aset digunakan untuk dibagikan kepada pemegang saham bukan untuk menambah modal internal perusahaan. Tingkat laba ini juga bisa digunakan perusahaan untuk melakukan ekspansi sehingga perusahaan mencoba untuk menyeimbangkan komposisi struktur modal dengan tingkat hutang yang tinggi pula. Tingkat hutang yang tinggi juga memberikan manfaat penghematan pajak bagi perusahaan.

\section{Pengaruh Struktur Aktiva dan Profitabilitas terhadap Struktur Modal}

Hasil pengujian statistik secara simultan menghasilkan nilai F hitung yaitu 24,430 lebih besar dari F tabel yaitu 4,10 dan nilai signifikan adalah 0.00 lebih kecil dari nilai 0.05. Dengan demikian struktur aktiva dan profitabilitas secara simultan berpengaruh terhadap struktur modal. Dengan ini pula dapat dinyatakan bahwa $\mathrm{H}_{3}$ dapat diterima. Hasil penelitian ini sesuai dengan penelitian sebelumnya yang dilakukan oleh Watung et al. (2016), Premawati \& Darma (2017), dan Maryanti (2016).

\section{E. KESIMPULAN DAN SARAN}

Penelitian ini menghasilkan bahwa setiap variabel independen struktur aktiva dan profitabilitas berpengaruh secara parsial terhadap variabel dependen struktur modal. Selain itu dapat dilihat bahwa variabel $\mathrm{X}$ secara simultan atau bersama-sama berpengaruh signifikan terhadap variabel struktur modal (Y). Dan untuk jumlah variabel dependen sebesar $84,4 \%$ sedangkan sisanya sebesar $13,6 \%$ dijelaskan oleh variabel atau faktor lain yang tidak dimasukkan ke dalam model ini. Nilai koefisien determinasi sebesar 84,4\% menunjukkan bahwa variabel bebas dalam penelitian memiliki pengaruh yang kuat. Jadi terbukti jika variabel independen struktur aktiva dan profitabilitas memang mempunyai dampak atau pengaruh yang besar dalam struktur modal di perusahaan. 
Penelitian ini dilakukan hanya menggunakan faktor atau variabel struktur aktiva dan probabilitas untuk menguji pengaruhnya terhadap struktur modal. Saran untuk penelitian selanjutnya yaitu untuk menambah faktor atau variabel lain yang memengaruhi struktur modal selain struktur aktiva dan probabilitas seperti pertumbuhan aktiva, risiko, ukuran perusahaan, pajak, struktur kepemilikan perusahaan, sistem pembayaran dari konsumen, kondisi pasar, dan lain sebagainya.

\section{DAFTAR PUSTAKA}

Andika, A. P., \& Fitria, A. (2016). Pengaruh Struktur Aktiva, Ukuran Perusahaan, Profitabilitas Dan Risiko Bisnis Terhadap Struktur Modal Perusahaan Perbankan Tahun 2011-2014. Jurnal Ilmu Dan Riset Akuntansi, 5(9), 1-19. http://jurnalmahasiswa.stiesia.ac.id/index.php/jira/article/view/2252

Andika, R. I. K., \& Sedana, I. B. P. (2019). Pengaruh Profitabilitas, Struktur Aktiva, Dan Ukuran Perusahaan Terhadap Struktur Modal. E-Jurnal Manajemen Universitas Udayana, 8(9), 5803. https://doi.org/10.24843/ejmunud.2019.v08.i09.p22

Anshori, M., \& Iswati, S. (2019). Metodologi Penelitian Kuantitatif: Edisi 1. Surabaya: Airlangga University Press.

Artini, L. G. S., \& Puspaningsih, N. L. A. (2011). Struktur Kepemilikan Dan Struktur Modal Terhadap Kebijakan Dividen Dan Nilai Perusahaan. Jurnal Keuangan Dan Perbankan, 15(1), 66-75.

Devi, N. M. N. C., Sulindawati, N. L. G. E., \& Wahyuni, M. A. (2017). Pengaruh Struktur Aktiva, Profitabilitas, Ukuran Perusahaan, Likuiditas, dan Kepemilikan Manajerial Terhadap Struktur Modal (Studi Empiris pada Perusahaan Manufaktur yang Terdaftar di Bursa Efek Indonesia Periode 2013-2015). E-Journal S1 Ak Universitas Pendidikan Ganesha, 7(1).

Dewi, D., \& Sudiartha, G. (2017). Pengaruh Profitabilitas, Ukuran Perusahaan, Dan Pertumbuhan Aset Terhadap Struktur Modal dan Nilai Perusahaan. E-Jurnal Manajemen, 6(4), 2222 - 2252.

Ghozali, I. (2016). Aplikasi Analisis Multivariate dengan Program IMB SPSS 23. Badan Penerbit Undip.

Hadianto, B. (2010). Pengaruh Struktur Aktiva, Ukuran Perusahaan, dan Profitabilitas Terhadap Struktur Modal Emiten Sektor Telekomunikasi Periode 2000-2006: Sebuah Pengujian Hipotesis Pecking Order. Jurnal Manajemen, 7(2), 14-29. https://media.neliti.com/media/publications/112355-ID-pengaruh-struktur-aktivaukuran-perusaha.pdf

Kanita, G. G. (2014). Pengaruh Struktur Aktiva dan Profitabilitas terhadap Struktur Modal Perusahaan Makanan dan Minuman. Trikonomika, 13(2), 127. https://doi.org/10.23969/trikonomika.v13i2.608

Maryanti, E. (2016). Analisis Profitabilitas, Pertumbuhan Perusahaan, Pertumbuhan Penjualan Dan Struktur Aktiva Terhadap Struktur Modal Pada Perusahaan Sektor 
Industri Barang Konsumsi Yang Terdaftar Di Bursa Efek Indonesia (Studi Empiris Pada Perusahaan Manufaktur yang Terdaftar di Bursa Efek Indonesia Tahun 2012-2014).

Riset Akuntansi Dan Keuangan Indonesia, 1(2), 143-151.

https://doi.org/10.23917/reaksi.v1i2.2730

Nawang, S. A. (2016). Pengaruh Profitabilitas, Likuiditas, Struktur Aset Dan Ukuran

Perusahaan Terhadap Struktur Modal. Jurnal Akuntansi \& Perpajakan, 2(3), 1-17. http://journal.untar.ac.id/index.php/JMDK/article/view/5359

Pertiwi, N.K.N, \& Darmayanti, N.P.A. (2018). Pengaruh Profitabilitas, Likuiditas, Struktur Aktiva Dan Kebijakan Dividen Terhadap Struktur Modal Perusahaan Manufaktur di BEI. E-Jurnal Manajemen Unud, 7(6), 3115-3143.

Prabansari, Y., \& Kusuma, H. (2005). Faktor-Faktor Yang Mempengaruhi Struktur Modal Perusahaan Manufaktur Go Public di Bursa Efek Jakarta. Sinergi Khusus on Finance, $1-15$.

Prastika, C. D., \& Sudaryanti, D. S. (2019). Pengaruh Struktur Aktiva Dan Profitabilitas Terhadap Struktur Modal (Penelitian Pada PT. Mayora Indah, Tbk.). Jurnal Ekonomi Manajemen, 5(1), 51-59.

Premawati, I. G. A. S., \& Darma, G. S. (2017). Pengaruh Ukuran Perusahaan, Pertumbuhan Penjualan, Struktur Aktiva, Dan Profitabilitas Terhadap Struktur Modal (Penelitian Di Bursa Efek Indonesia Periode 2011-2015). Jurnal Ilmiah Akuntansi \& Bisnis, 2(2), 272-286.

Sudarmika, G., \& Sudirman, I. (2015). Pengaruh Profitabilitas, Pertumbuhan Aktiva, Struktur Aktiva, Dan Pajak Terhadap Struktur Modal. E-Jurnal Manajemen Universitas Udayana, 4(9), 254468.

Sugiyono. (2012). Metode Penelitian Bisnis. Alfabeta.

Sukamulja, S. (2019). Analisis Laporan Keuangan sebagai Dasar Pengambilan Keputusan Investasi. Yogyakarta: ANDI.

Sulaiman, W. (2004). Analisis Regresi Menggunakan SPSS: Contoh Kasus \& Pemecahannya. Yogyakarta: Andi.

Suweta, N., \& Dewi, M. (2016). Pengaruh Pertumbuhan Penjualan, Struktur Aktiva, Dan Pertumbuhan Aktiva Terhadap Struktur Modal. E-Jurnal Manajemen Unud, 5(8), 254359.

Thausyah, N. F., \& Suwitho, S. (2015). Pengaruh Pertumbuhan Penjualan, Struktur Aktiva Dan Profitabilitas Terhadap Struktur Modal. Jurnal Ilmu Dan Riset Manajemen, 4(9), $1-15$.

Tijow, A. P., Sabijono, H., \& Tirayoh, V. Z. (2018). Pengaruh Struktur Aktiva Dan Profitabilitas Terhadap Struktur Modal Pada Perusahaan Sektor Industri Barang Konsumsi Yang Terdaftar Di Bursa Efek Indonesia. Going Concern : Jurnal Riset Akuntansi, 13(04), 477-488. https://doi.org/10.32400/gc.13.03.20375.2018

Watung, A. K. S., Saerang, I. S., \& Tasik, H. H. D. (2016). Pengaruh Rasio Likuiditas, Aktivitas, Profitabilitas, dan Struktur Aktiva Terhadap Struktur Modal Industri Barang Konsumsi di Bursa Efek Indonesia. Jurnal EMBA, 4(2), 726-737. 
Wijaya, I., \& Utama, I. (2014). Pengaruh Profitabilitas, Struktur Aset, Dan Pertumbuhan Penjualan Terhadap Struktur Modal Serta Harga Saham. E-Jurnal Akuntansi, 6(3), 514530.

Yusintha, P., \& Suryandari, E. (2010). Analisis Faktor-Faktor Yang Mempengaruhi Struktur Modal. Jurnal Akuntansi Dan Investasi, 11(2), 179-188.

Yusuf, D., \& Yusra, I. (2019). Faktor-Faktor Yang Mempengaruhi Struktur Modal Perusahaan. 4(September). https://doi.org/10.31227/osf.io/wk4ut

Zuhro, F. (2016). Pengaruh Ukuran Perusahaan, Pertumbuhan Aset, dan Profitabilitas terhadap Struktur Modal. Jurnal Ilmu Dan Riset Manajemen, 5(5), 1-16. 